\title{
The New Goal and Path Choice of the Development of China's Vocational and Technical Education
}

\author{
Xiaohong Feng \\ Chongqing Vocational and Technical University of Mechatronics, Chongqing 402760, China
}

About the author: Xiaohong Feng, Vice President of Chongqing Vocational and Technical University of Mechatronics. Her research interests include higher vocational education and teacher team construction.

Funding: Chongqing higher education teaching reform research major project: "Chongqing Vocational Education (undergraduate level) construction research and practice" (Project No. 191039); Key projects of Chongqing Education Science Planning(Project No. 2018-GX-040).

\begin{abstract}
The development of China's Vocational and technical education is the inevitable product of the times, which has important practical significance. The definition of the training objectives of undergraduate talents in Vocational Education in China should be placed in the whole higher education system, especially in the distinction between junior college and undergraduate; It is the difference between general education and vocational education in undergraduate level. In order to carry out the reform smoothly and effectively, we should always focus on the goal of talent training, improve the professional level of the school by deepening the integration of production and education, enhance the technical ability of students by strengthening the cooperation between school and enterprise, and guarantee the teaching quality of the school by paying close attention to the teaching staff.
\end{abstract}

Key words: Vocational education; Personnel training objectives; China Policy

Publication date: April, 2021; Publication online: 30 April, 2021

*Corresponding author: Xiaohong Feng, 2725763371@qq.com

\section{Introduction}

The establishment of higher education institutions in China has expanded from junior college level to undergraduate level vocational and technical colleges from 2018. By 2020, China's Ministry of education has selected and constructed 22 pilot vocational education schools in batches. China has entered a new era to carry out a new round of Vocational and technical education reform in China Pilot applied undergraduate level vocational and technical schools (hereinafter referred to as: Vocational Education (undergraduate) should maintain the specialty of professional orientation; We should attach equal importance to the cultivation of applied theoretical knowledge and on-the-spot professional key abilities in curriculum and teaching; Pay attention to the flexible teaching methods in the applied vocational and technical college. The pilot reform of undergraduate vocational education led by China's Ministry of education is a major breakthrough for the Chinese government to comprehensively build a modern vocational education system and improve China's modern vocational education system.

\section{Oriented to industrial demand: The practical} needs of the new development stage of China's

\section{Vocational and technical education}

Under the strategic background of the "double cycle" new development pattern, China reorients the talent training goal of Vocational and technical education, and points its development goal to the talent training of various types of industries facing the actual needs of industries, which can meet the diversified and high-level needs of various emerging industries for vocational education, and promote industrial transformation and upgrading and healthy and sustainable economic development. 
2.1 From the evolution of vocational education policy, we can see the goal orientation of China's Vocational and technical education policy development

Looking back on a series of important national policies on Vocational Education in China from 1980 to 2020, the development of Vocational and technical education in China has experienced three important stages since 1980. The first stage is to adjust the structure of secondary vocational education and promote its rapid development; The second stage is to develop and popularize vocational education at the junior college level; The third stage is to explore the undergraduate level higher vocational education and improve the modern vocational education system. There are also three obvious leaps in the construction of vocational education framework system. From 1980 to 2000, the establishment of vocational education system and basic framework was proposed; From 2000 to 2010, the concept of modern vocational education system was put forward and its connotation was gradually enriched; From 2010 to 2020, it is clearly proposed to explore the development of vocational education undergraduate.

2.2 From the perspective of the development of vocational education system, China's Vocational and technical education has entered a new stage of undergraduate development and the pursuit of highquality development

The rapid development of China's Vocational and technical education since the 1980s has actually entered a new stage of development. In 2019, China's State Council vocational education reform implementation plan issued by China's State Council pointed out that Xi Jinping should take occupation education as a guide in the new era of socialism with Chinese characteristics and put more emphasis on occupation education in the reform, innovation and economic and social development. From seven aspects and 20 items, the plan puts forward that we must pay great attention to the development of vocational education, and designs "how to grasp" and specific reform measures from the top. This is the country's new attitude towards vocational education, new judgment on the situation of vocational education, and new definition of the status of vocational education, which has far-reaching practical and historical significance[1]. The system construction of China's Vocational and technical education is not perfect, so we should strengthen the improvement from the aspects of vocational education system and high-level applied talents training system, and "carry out the undergraduate pilot of vocational education". As another kind of education as important as general education, higher vocational education used to be confined to the category of level education, resulting in the lack of channels for higher vocational students to improve their academic qualifications. Vocational college level students can only be promoted to the undergraduate level of general education and strengthen theoretical learning, but they cannot improve their professional ability. Higher vocational education should have a corresponding development channel of vocational education. It is necessary to improve the academic level within the vocational education system, form the vocational education of college, undergraduate and graduate level, which develops in parallel with general education, and form a perfect modern vocational education system.

\subsection{On the mission of China's Vocational and technical education from the perspective of economic construction}

With the transformation of China's economic growth mode and the transformation and upgrading of industrial structure, the speed of high-tech industrialization is accelerated, the production environment is more complex, the technical requirements are higher and stricter, the market demand structure for talents is improved, and the talent supply structure, scale and quality of higher education must match the talent demand. In a market economy, demand is the driving force. In order to enhance China's competitiveness in the international community, high-quality economic and social development requires broad and solid theoretical knowledge, flexible application of high-tech, and solving practical production problems. "The law of social relations of education requires that education must adapt to social development, and the talent training structure must actively adapt to the demand structure of modern economy and Society for talents"[2]. China's Vocational and technical education, as an important support for the rational allocation of talents for industrial development, should be combined with the needs of industrial structure adjustment to enhance the level of talent training, undertake the task of higher specification and higher level of talent training, and shoulder the responsibility of solving the structural contradiction of university graduates: ineffective talent supply surplus, but effective talent supply shortage. Therefore, the vocational education undergraduate course must have a higher vision and vision, integrate into the background of national development and national revitalization, and fulfill its mission and 
responsibility in a more realistic and in-depth integration of industry and education, school enterprise cooperation, service the healthy development of modern industry, and promote the sustainable development of students.

\section{The goal of talent development: The value pursuit of China's Vocational and technical education in the new development stage}

\subsection{Reasonable orientation of training objectives of Vocational Education Undergraduates in higher education system}

China's vocational education covers all types of "TVET" determined by UNESCO in $1999^{[5]}$. Chinese universities are divided into research type and application type. According to the structure of knowledge and ability, talents can be divided into academic type, engineering type, technical type and skill type $^{[3-4]}$. The boundary between the two types of talents is fuzzy, and may even overlap. With the progress of science and technology and the development of productive forces, this fuzzy boundary will change. In the constant change, new types of talents may emerge. According to the particularity of different majors and the development level of different industries and regions, the classification of talent types may also change dynamically. Different types of education basically define different types of schools, different types of schools basically define different allocation of educational resources, different teaching contents and teaching methods, thus basically defining different orientation of talent cultivation. According to this, we can construct the frame map of higher education, colleges and talent training.

3.2 It emphasizes the difference between undergraduate and junior college in vocational education, and focuses on the development of Higher Vocational and technical education at undergraduate level

Vocational education focuses on the cultivation of students' practical skills, and promotes the improvement of social productivity and economic and social development through the cultivation of front-line talents in production, management and service at different levels. As can be seen from Figure 1, vocational schools at the undergraduate level and vocational schools at the junior college level cultivate technical talents and skilled talents respectively. They are both applied talents, and both emphasize practical ability.
Skilled talents strengthen specific job requirements, mainly engaged in a "point" skill operation, can apply certain raw materials and production tools, and solve production process problems according to established standardized thinking and regular thinking of production mode ${ }^{[6]}$; Skilled talents are proficient in the technology chain of the whole production line, mainly engaged in the application, practice, development and innovation of related technology of a "line", able to use and develop new production materials, equipment and technology, able to innovate production procedures, integrate dynamic principled thinking in the production process and experiential thinking in the actual state, and form innovative thinking ability to solve technical problems ${ }^{[7]}$.

3.3 This paper distinguishes the difference of professional ability between general education and vocational education, and emphasizes the training and cultivation of Vocational and technical post competency

The difference between general education and vocational education in the same undergraduate level mainly refers to the difference between the application-oriented school in general education and the vocational school in the undergraduate level in vocational education. As can be seen from Figure 1, application-oriented schools mainly cultivate engineering talents. Engineering talents are mainly engaged in the overall decision-making, planning and design of practical activities in a whole "face" professional field ${ }^{[8]}$. Engineering talents need to master the skills and technologies of related majors or related fields, but they don't need to be proficient, and pay more attention to the systematicness and integrity of the professional field. In other words, engineering talents focus on: We need to have a deep theoretical foundation, focus on the expertise of all walks of life, and comprehensively integrate the relevant professional theoretical knowledge, so as to transform new technology and new knowledge into productivity (including management ability and service ability, etc.). Such as engineers, teachers, doctors and management cadres. The key points of technical talents training in undergraduate vocational schools are as follows: It needs to have strong practical ability, operation technology, skills, organization and coordination ability, as well as the ability to deal with emergencies on site. 


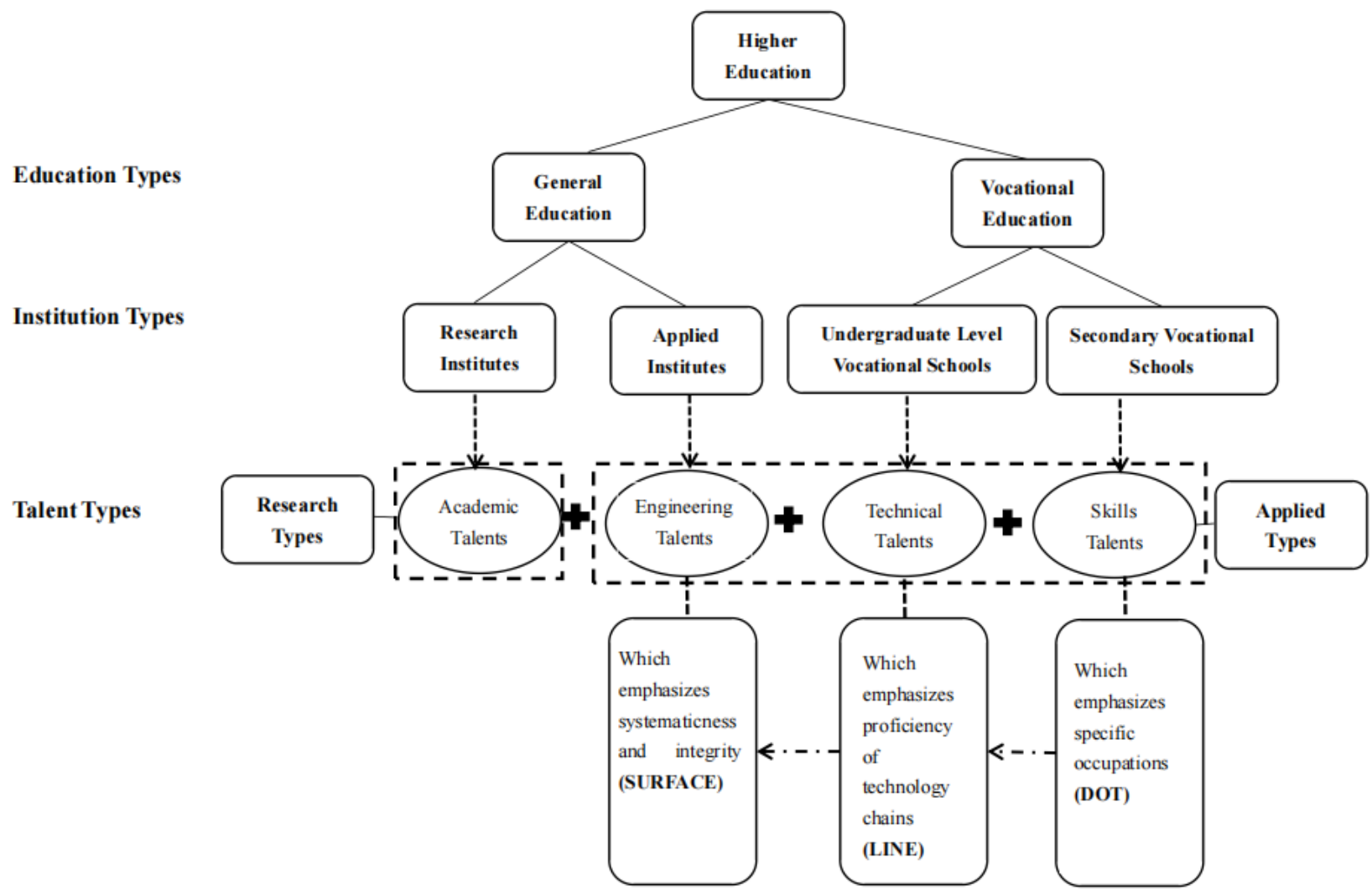

Figure 1. The positioning framework of higher education, universities and personnel training

4 Guidance for social needs: The path choice of the new development stage of China's Vocational and technical education

\subsection{Improve the professional level of the school by deepening the integration of production and education}

Vocational education has the attributes of occupation, lifelong and regional. In the process of continuously serving the local economic and social development, we should fully integrate policies and measures, make use of regional industrial advantages, and innovate the system and mechanism; In the process of integrating into local and industry, optimize the allocation of resources, gather multi-party forces, promote the industry and enterprises to actively participate in the school professional construction, and enhance the adaptability of vocational education. At present, China has cultivated more than 800 industry education integration enterprises and established more than 1400 vocational education groups. Deepen the integration of industry and education, use the cross-border (Education + industry) training mode, and participate in the whole training process of students. According to the changes of new market and new technology, the professional construction plan and measures should be adjusted accordingly; The whole process focuses on the integration of students' educational cognition and the law of career growth, so as to avoid the disadvantages of single subject training in traditional schools. Through the combination of knowledge and practice and the combination of work and study, we can improve the professional level of the school and enhance the feasibility of training technical talents.

\subsection{Enhance students' technical ability by strengthening school enterprise cooperation}

In the new era, strengthening school enterprise cooperation is the only way to conform to industrial development and talent training. In modern western education theory, Comenius, the founder of Comenius, once put forward some important teaching principles in the great teaching theory, such as intuition and convenience, thoroughness of induction, simplicity and gradualness, etc. These principles still have important guiding significance for the current teaching activities of vocational education undergraduate teachers. For example, according to the characteristics of Vocational Students' perception and acceptance of knowledge and skills, the principle of intuitionistic convenience is to make students learn happily by intuitionistic, simple and clear way. For 
example, through joint ventures to strengthen the implementation of the development of various forms of new teaching materials, such as the new loose leaf or work manual type of teaching materials, to facilitate students to fully grasp the theoretical knowledge of new technology in a simplified way; Then, by staggering the production schedule of enterprises and flexibly setting up practical courses, more opportunities for students to practice in enterprises can be created, so that students can acquire tacit knowledge of technology, form good professional habits, and cultivate the ability to deal with emergencies at work. The realization of this teaching mode must strengthen the cooperation between school and enterprise. Strengthen enterprises, enhance the social responsibility of vocational education, promote the cooperation between Vocational Colleges and industry enterprises, and form a community of common destiny; Through bold reform attempts, give play to the internal initiative of both schools and enterprises, so as to improve the students' technical ability and the adaptability of students' development.

\subsection{Guarantee the teaching quality of the school by strengthening the teaching staff}

Mr. Tao Xingzhi, a famous Chinese educator, puts forward the educational idea of "integration of teaching, learning and practice", which advocates the organic unity of teachers' teaching, students' learning and practical practice. Only when teachers know how to do things, can they organize how to teach and guide students how to learn. Teachers are the first resource of vocational education development and the key force of reform. The obvious difference between the construction of teachers in vocational education and that in general education is to strengthen the construction of "double Higher Education, 2015(2): 34-39.

[6] Chen XY. The Value of "Establishing People" in Vocational Education: A Review of Technology Philosophy [J].Vocational Education Forum, 2014(4): 8-13.

[7] Che RS, Ji HB. Analysis of the concept of applied innovative talents $[\mathrm{J}]$. College Education Management, qualified" teachers. In the "20 items of vocational education", it is clear that vocational education in the new era should effectively build a "double qualified" teaching team through a variety of ways, channels and measures. Specific requirements and measures are put forward in the introduction, training and promotion of teachers. For example, teachers are required to train in enterprises or training bases for at least one month every year to form a high-level and well structured teacher education and teaching innovation team. Therefore, great efforts must be made to enhance teachers' mastery of new technology, effectively guide students to learn relevant theoretical knowledge and improve relevant practical ability, so as to ensure the quality of school teaching.

\section{References}

[1] Feng XH. Exploration on the Construction of "Doublequalified" Teachers in Undergraduate Vocational Schools [J]. Modern Vocational Education, 2019(5): 304-305.

[2] Tang LW. Thinking on the Development of Higher Vocational Education at Undergraduate Level from the Perspective of Philosophy of Technology [J]. Research in Higher Education, 2015(2): 34-39.

[3] Zhou JS. Construction of Modern Vocational Education System and Innovative Development of Higher Vocational Education [M]. Zhejiang Gongshang University Press, 2017,11 .

[4] Feldman K. Research Productivity and Scholarly Accomplishments of College Teachers as Related to Their Instructional Effectiveness: Explo-ration and explo-ration [J]. RCSCARCH in Higher Education. 1987(25) 227-298

[5] Tang LW. Thinking on the Development of Higher Vocational Education at Undergraduate Level from the Perspective of Philosophy of Technology [J].Research in 2015(1): 81-85.

[8] Lu SJ. Implementing Vocational Education Undergraduate is an Important Measure to Improve China's Vocational Education System [J]. Research on Educational Development, 2019(7): 35-41. 